\title{
Zoonotic Escherichia coli
}

\author{
By Yngvild Wasteson
}

Department of Pharmacology, Microbiology and Food Hygiene, The Norwegian School of Veterinary Science, Postbox 8146 Dep., N-0033 Oslo, Norway.

\begin{abstract}
Escherichia coli is a normal inhabitant of the gastrointestinal tract of all warm-blooded animals, but variants of this species is also among the important etiological agents of enteritis and several extraintestinal diseases. The E. coli strains that cause diarrhoeal illness are categorised into pathogenicity groups based on virulence properties, mechanisms of pathogenicity, clinical symptoms and serology. The five main categories include enterotoxinogenic E. coli (ETEC), enteropathogenic E. coli (EPEC), enteroaggregative E. coli (EAggEC), enteroinvasive E. coli (EIEC) and Shiga (Vero) toxin-producing E. coli (STEC/VTEC). From a zoonotic point of view, STEC is the only E. coli pathogenicity group of major interest, as the shiga toxin-producing strains are able to cause severe disease in humans when being transmitted through the food chain from their animal reservoirs. The focus of this manuscript is therefore on STEC; pathogenicity factors, disease, the reservoirs and on-farm ecology, transmission into the food chain, growth and survival in food and in the environment, and the shiga toxin-encoding bacteriophages.
\end{abstract}

E. coli, shigatoxins, pathogenicity, reservoirs and on-farm ecology, transfer to humans.

\section{Introduction}

Escherichia coli was first described in 1885 by the German bacteriologist Theodore Escherich, and was then named Bacterium coli commune. The bacterium was isolated from feces from a healthy infant. Until the 1950's the organism was more or less regarded as a normal nonpathogenic cohabitant of the enteric tract of warm-blooded animals and humans. However, during the last four-five decades, a tremendous amount of research has established E. coli among the important etiological agents of enteritis and several extraintestinal diseases such as urogenital infections, wound infections, mastitis, septicaemia and meningitis.

\section{Diarrheagenic E. coli}

To distinguish between friends and foes of the E. coli species, the E. coli strains that cause diarrhoeal illness are categorised into pathogenicity groups based on virulence properties, mechanisms of pathogenicity, clinical symptoms and serology. The five main categories include enterotoxinogenic E. coli (ETEC), enteropathogenic E. coli (EPEC), enteroaggregative E. coli (EAggEC), enteroinvasive E. coli (EIEC) and Shiga (Vero) toxin-producing E. coli (STEC/VTEC) (reviewed by Nataro \& Kaper 1998).

ETEC strains are characterized by their ability to produce enterotoxins and adhesive fimbriae. The enterotoxins are classified according to their thermal stability into two main groups; heat-stable and heat-labile. The fimbriae are filamentous structures and show restricted species specificity by adhering to specific receptors on the intestinal epithelium. ETEC strains are a 
major cause of infantile diarrhoea in developing countries, are frequently associated with traveller's diarrhoea and diarrhoea in the very young animals as piglets, lambs and calves. However, due to the species-specific binding of the fimbrial adhesins, ETEC is not regarded as a zoonotic agent.

The most important virulence factor of EPEC strains is their ability to induce attaching and effacing lesions in cells to which they adhere, and thereby invade epithelial cells. In developing countries infection with EPEC strains is a major cause of diarrhoea in children. As for ETEC, drinking water contaminated with human waste and sewage is an important source of infection with EPEC.

The role of EAggEC as an enteropathogen is still somewhat debatable, but EAggEC strains have been associated with chronic diarrhoea in children. In vitro, they have been shown to produce a pattern of aggregative adherence on HEp2 cells, and some strains produce a heat stable enterotoxin that may be relevant for their pathogenicity.

EIEC strains cause disease in humans similar to the disease caused by infections with Shigella spp. In contrast to the other E. coli pathogenicity groups, these strains are able to invade and multiply within colonic epithelial cells.

From a zoonotic point of view, STEC is the only E. coli pathogenicity group of major interest, as the shiga toxin-producing strains are able to cause severe disease in humans when being transmitted through the food chain from their animal reservoirs. The focus of the rest of this manuscript will therefore be on STEC.

\section{Shiga toxin-producing E. coli}

E. coli $\mathrm{O} 157: \mathrm{H7}$ can be regarded as the prototype of the STEC causing disease in humans. STEC strains of this serotype have been the cause of a number of food- and waterborne outbreaks and also of numbers of sporadic cases all over the world, since the first hamburger-borne outbreaks were registered in USA in 1992-93. However, four other serogroups (O26, O103, O111 and O145) have now been identified as emerging pathogens in Europe. Clearly, there is a great need for more knowledge about the reservoirs, the epidemiology and the sources of the human pathogenic non-O157 STEC, as documented in a report from WHO in 1998.

The main virulence characteristic of STEC is the production of a toxin, which is cytotoxic to Vero cells in vitro, and closely related to the Shiga toxin of Shigella dysenteriae (Nakao \& Takeda 2000). E. coli Shiga toxins consist of two families; stx 1, a homogenous group of toxins virtually identical to the Shiga toxin of $S$. dysenteriae and stx2, a heterogenous group of toxins more distantly related to the Shiga toxin. A number of $s t x 2$ variants have been described, all of which are distinguishable by PCR. Additional virulence-associated properties have been described, such as the production of attaching-effacing lesions and the secretion of plasmid-mediated haemolysins.

The spectrum of disease in humans caused by STEC can range from mild to severe bloody diarrhoea (Nakao \& Takeda 2000). Complications including haemolytic uremic syndrome (HUS) and thrombotic thrombocytopenic purpura (TTP) can occur in some cases (Nakao \& Takeda 2000). HUS can cause chronic kidney damage, which may require dialysis and possible need for transplant. The clinical features of TTP are similar to HUS, but are further complicated and overshadowed by neurological manifestations. The majority of cases, however, present as bloody diarrhoea (haemorrhagic colitis, HC) after a typical incubation period of 34 days (Coia 1998). A significant percentage $(10 \%)$ of patients develop HUS or other serious complications. Overall, approximately $0.6 \%$ of cases are fatal, and pre-school children and the elderly are particularly at risk. The infectious 
dose is lower than for many other enteric pathogens and has been reported to be fewer than 50 organisms.

STEC strains have been recovered from faeces or intestines of a wide range of both domesticated and wild animals and birds. However, its role as the causative agent of disease has only been demonstrated in cattle ("calf dysentery"), pigs ("oedema disease") and dogs ("Alabama rot") (Mainil 1999). In most animals, the organism may be carried and excreted by the animals in the absence of disease. Cattle have been recognised as the most important vector in relation to human infection, being symptomless excretors releasing strains indistinguishable from those causing human disease, of serotype O157:H7 in particular, into the environment and the human food chain.

A lot of research has been conducted throughout the last ten years to elucidate the ecology of E. coli O157:H7 in cattle and on cattle farms, and the majority of this research has been done in USA (Hancock et al. 1998a+b, Hancock et al. 1997a+b, Hancock et al. 2001). Keeping this in mind, some generalizations about the ecology can be proposed. E. coli $\mathrm{O} 157: \mathrm{H} 7$ has a near-ubiquitous distribution in the US cattle farms. In healthy individual animals, E. coli O157:H7 reside as a transient organism in the gastrointestinal flora, while temporal clustering at the population level is frequently observed. Consequently, at population level most faecal shedding is confined to sharp bursts in a high percentage of animals separated by much longer periods of very low prevalence. Generally, a higher prevalence in young animals in comparison to older ones is seen, and a higher prevalence is also observed in animals with a disturbed gastrointestinal flora, such as due to transit and feed changes. A marked peak in shedding during the warm months correlates with a similar peak in outbreaks of human disease. By use of molecular subtyping methods, is has been shown that, despite the transient residence in individual animals, subtypes of E. coli O157:H7 can persist on cattle farms for years. It is yet not clear whether the cattle themselves are the long-term reservoir, or whether the organism persists in other niches at the farm. Commercial feeds are sometimes contaminated with E. coli O157:H7 (Hancock et al. 2001), and it seems likely that feeds represent an important route of dissemination of this agent. Water troughs are also commonly positive for E. coli $\mathrm{O} 157: \mathrm{H} 7$, and feed and water likely represent the most common means of infection. Traditional means of controlling infectious agents, such as eradication or test and removal of carrier animals, do not appear to be feasible for STEC. Nevertheless, certain farm management practices, especially those related to maintenance and multiplication of the agent in the feed and water, may provide practical means to reduce the prevalence of these agents in cattle.

There is no data available on E. coli $\mathrm{O} 157: \mathrm{H} 7$ or other STEC in Nordic organic farming, making it impossible to consider whether the proposed "US-ecology" of E. coli $\mathrm{O} 157: \mathrm{H} 7$ is very different in this management system. In general, Norway experiences a low occurrence of E. coli O157:H7 in their dairy cattle population; two studies of E. coli $\mathrm{O} 157: \mathrm{H7}$ in dairy cattle in 1995 and 1998/99 gave herd prevalences of 1\% and $0.35 \%$, respectively (Vold et al. 1998, Johnsen et al. 2001). In Denmark, a survey done in 1999 in 60 herds in South Jutland, 10 of the herds $(17 \%)$ were positive for $E$. coli O157:H7 (Nielsen 2001). A nested case control study based on dairy cattle faecal samples positive for $s t x_{1}$ and /or stx $x_{2}$ in Norway, showed that loose housing dairy barns turned out to be the major risk factor for the occurrence of $s t x_{2}$, while purchase of animals and pasture contact with other herds were not identified as important risk factors (Vold et al. 1999). Presumably, 
the most likely biological risk linked to loose housing is the spread of the gene in the herd due to a more intense faecal-oral contact in such herds compared to traditionally confined herds. Studies have been done to investigate the interaction between feed and structure and excretion of $E$. coli $\mathrm{O} 157: \mathrm{H} 7$ in cattle and sheep. When comparing grain-fed animals to animals fed hay, the latter shed the bacteria for a longer period than the former (Kudva et al. 1997, Hovde et al. 1999). Dietary changes also have an impact on the speed of cell proliferation in the gastrointestinal tract, which again may influence on the shedding of E. coli O157:H7 (Magnuson et al. 2000). This may be relevant to consider in the context of organic farming, where feeding regimes and diets are less based on commercial grain feed compared to traditional farming. Faecal contamination is one of the primary contributory factors to the persistence of STEC in the environment and contributes to the transmission of STEC to humans through the contamination of food crops and water sources, and through direct contact. Because of the low infectious dose level of $E$. coli $\mathrm{O} 157: \mathrm{H} 7$, any survival or potential for growth can have serious food safety consequences. Information on the survival of STEC in the food chain including in the live animal, the environment, and during food processing and storage is essential for the development of measures, which limit the survival potential of STEC and reduce the risks posed by this pathogen. The food industry is constantly moving toward milder forms of food preservations, and thus knowledge on survival of STEC is of particular importance to the food industry.

STEC has been shown to survive very well in faeces; in particular low temperatures and high moisture will enhance its survival (Bolton et al. 1999, Maule 1999). Experiments have shown that when faeces containing STEC was deposited on grass, the organism was transferred to the soil where it was detected even after the faeces had decomposed. On soil cores containing rooted grass, E. coli O157:H7 was demonstrated to persist for several months. Long-term survival has also been observed in fresh manure, while a rapid decrease seems to occur in slurry. However, the practice of applying either slurry or fresh manure to land has been shown to transfer STEC to food crops and surface water. The risk of significant contamination of surface water after such application was in experiments highest immediately after application of slurry, and the first increments of drain flow carried significant concentrations of the organism. The use of such contaminated water for irrigation of food crops and washing of fruit and vegetables have also been identified as transmission routes for STEC. In addition, a number of waterborne outbreaks of STEC infections have been attributed either to people swimming in contaminated water or to the consumption of contaminated potable water. In nutrient deficient water, STEC survives poorly, but low temperatures and faecal contamination can extend survival for several months. Faecal contamination of water provides a nutrient rich environment, which can support both the survival and growth of STEC.

The genes encoding the Shiga toxins in STEC are located on lysogenic lambdoid bacteriophages. According to recent research, the Stx phages should not be viewed as passive vectors for the dissemination of the toxin genes, but genetic entities where the characteristics of the phage itself influences virulence of the host bacterium (Wagner et al. 1999). Moreover, intra-intestinal transmission of phages has been demonstrated between E. coli strains (Acheson et al. 1998). Consequently, it may be hypothesised that the phage genotype may influence on the transmission of stx between bacteria, and thus, the spread and emergence of STEC. It has been shown that free infective Stx phages sur- 
vived longer than bacterial cells in water exposed to adverse environmental conditions and also were more resistant to chlorination of sewage (Muniesa \& Jofre 1998, Muniesa et al. 1999). The full implications of this research on toxin encoding phages have yet to be determined.

In summary, STEC is considered as a serious public health issue in light of the severity of the illness and the potential for fatalities as a result of poisoning by this pathogen. Faecal contamination is the primary contributory factor to the persistence of STEC in the environment, and it also contributes to the transmission of STEC to animals and humans through the contamination of food crops and water sources, and from direct contact. The most important preventive measure to reduce the risk posed by this pathogen is to reduce the level of faecal contamination, at the herd level, of the environment, of raw food and water and through food processing and storage.

\section{References}

Acheson DW, Reidl J, Zhang X, Keusch GT, Mekalanos JJ, Waldor MK: In vivo transduction with shiga toxin 1-encoding phage. Infect. Immun. 1998, 66, 4496-4498.

Bolton DJ, Byrne CM, Sheridan JJ, McDowell DA, Blair IS: The survival characteristics of a nontoxigenic strain of Escherichia coli O157:H7. J. Appl. Microbiol. 1999, 86, 407-411.

Coia, J: 1998. Clinical, microbiological and epidemiological aspects of Escherichia coli $\mathrm{O} 157$ infection. FEMS Immunology and Medical Microbiology 20, 1-9.

Hancock DD, Besser TE, Rice DH: Ecology of Escherichia coli $\mathrm{O} 157: \mathrm{H} 7$ in cattle and impact of management practices. In: Escherichia coli and other Shiga toxin-producing E. coli strains, edited by Kaper JB and O'Brien AD, Washington D.C., ASM Press, 1998a, 85-91.

Hancock DD, Besser TE, Rice DH, Ebel ED, Herriott $D E$, Carpenter $L V$ : Multiple sources of Escherichia coli $\mathrm{O} 157$ in feedlots and dairy farms in the northwestern USA. Prev.Vet. Med. 1998b, 35, 11-19.
Hancock DD, Rice DH, Herriott DE, Besser TE, Ebel $E D$, Carpenter $L V$ : Effects of farm manure-handling practices on Escherichia coli $\mathrm{O} 157: \mathrm{H7}$ prevalence in cattle. J. Food Prot. 1997a, 60, 363366.

Hancock DD, Rice DH, Thomas LA, Dargatz DA, Besser TE: Epidemiology of Escherichia coli O157 in feedlot cattle. J. Food Prot. 1997b, 60, 462-465.

Hancock, DD, Besser T, Lejeune J, Davis M, Rice D: The control of VTEC in the animal reservoir. Int. J. Food. Microbiol. 2001, 66, 71-78.

Hovde CJ, Austin PR, Cloud KA, Williams CJ, Hunt $C W$ : Effect of cattle diet on Escherichia coli O157:H7 acid resistance. Appl. Environ. Microbiol. 1999, 65, 3233-3225.

Johnsen G, Wasteson Y, Heir E, Berget OI, Herikstad $H$ : Escherichia coli O157:H7 in faeces from cattle, sheep and pigs in the southwest part of Norway during 1998 and 1999. Int. J. Food Microbiol. 2001, 65, 193-200.

Kudva IT, Hunt CW, Williams CJ, Nance UM, Hovde $C J$ : Evaluation of dietary influences on Escherichia coli O157:H7 shedding by sheep. Appl. Environ. Microbiol. 1997, 63, 3878-3886.

Magnuson BA, Davis M, Hubele S, Austin PR, Kudva IT, Williams CJ, Hunt CW, Hovde CJ: Ruminant gastrointestinal cell proliferation and clearance of Escherichia coli O157:H7. Infect. Immun. 2000, 68, 3808-3814.

Mainil J: Shiga/Verocytotoxins and Shiga/verotoxigenic Escherichia coli in animals. Vet. Research 1999, 30, 235-257.

Maule A: Environmental aspects of E. coli O157: Intern. Food Hygiene 1999, 9, 21-23.

Muniesa M, Jofre J: Abundance in sewage of bacteriophages that infect Escherichia coli O157:H7 and that carry the Shiga toxin 2 gene. Appl. Environ. Microbiol. 1998, 64, 2443-2448.

Muniesa M, Lucena F, Jofre J: Comparative survival of free Shiga toxin 2-encoding phages and Escherichia coli strains outside the gut. Appl. Environ. Microbiol. 1999, 65, 5615-5618.

Nakao H, Takeda T: Escherichia coli Shiga toxin. J. Natural Toxins 2000, 9, 299-313.

Nataro, JP, Kaper JB: Diarrheagenic Escherichia coli. Clin. Microbiol. Rev. 1998, 11, 142-201.

Nielsen EM: Epidemiologi of VTEC O157 in cattle farms: seasonal variation and persistence of strains. Proceedings from VTEC Concerted Action CT98-3935 meeting; Epidemiology of VTEC, Malahide, Ireland, Febr. 8-10, 2001. 
Vold L, Wasteson Y, Skjerve E: Risk factors associated with the occurrence of stx2 in Norwegian dairy cattle herds. Acta Clin. Belgica 1999, 54-1, 50.

Vold L, Klungseth Johansen B, Kruse H, Skjerve E, Wasteson Y: Occurrence of shigatoxinogenic Escherichia coli $\mathrm{O} 157$ in Norwegian cattle herds. Epidemiol. Infect. 1998, 120, 21-28.

Wagner PL, Acheson DWK, Waldor MK: Isogenic lysogens of diverse Shiga toxin 2-encoding bacteriophages produce markedly different amounts of Shiga toxin. Infect. Immun. 1999, 67, 67106714 .

\section{Sammendrag}

Zoonotiske Escherichia coli

Escherichia coli er en vanlig forekommende bakterieart i tarmfloraen hos alle varmblodige dyr og mennesker. E. coli er imidlertid også et viktig etiologisk agens i forbindelse med lidelser i tarmkanalen og andre ekstraintestinale sjukdommer. De E. coli stammene som er årsak til ulike diarétilstander kan klassifiseres i patogenitetsgrupper på bakgrunn av deres innhold av patogenitetsfaktorer, patogenese, kliniske symptomer og serologi. De fem hovedgruppene inkluderer enterotoksiske E. coli (ETEC), enteropatogene E. coli (EPEC), enteroaggregative $E$. coli (EAggEC), enteroinvasive E. coli (EIEC) and Shiga (Vero) toksin-produserende E. coli (STEC/VTEC). STEC er den eneste av disse gruppene av særlig zoonotisk interesse, ettersom STEC kan overføres fra dyr til menneske gjennom fekal forurensing av mat og vann, og ved direkte kontakt med bærerdyr. Dyra som er bærere av STEC er sjelden syke, men STEC kan forårsake svært alvorlig sjukdom hos menneske, av og til med fatal utgang. Fokus i denne oversiktsartikkelen er derfor på STEC og deres patogenitetsfaktorer, sjukdom, forekomst hos dyr og faktorer som kan ha innvirkning på denne forekomsten. Videre omhandler artikkelen egenskaper og karakteristika ved bakterien og deres toksin-kodende bakteriofager som har betydning for vekst og overlevelse i næringskjeden. 